\title{
ANALISA PEMANFAATAN LEARNING MANAGEMENT SYSTEM (LMS) SEBAGAI MEDIA PEMBELAJARAN ONLINE SELAMA PANDEMI COVID-19
}

\author{
Yuni Fitriani \\ Program Studi Sistem Informasi \\ Fakultas Teknologi Informasi \\ Universitas Bina Sarana Informatika \\ yuni.yfi@bsi.ac.id
}

\begin{abstract}
ABSTRAK
Pandemi COVID-19 menuntut sektor pendidikan untuk melakukan berbagai perubahan maupun inovasi dan adaptasi demi pelaksanaan proses pembelajaran tetap berjalan baik. Pandemi COVID-19 mendorong sektor pendidikan terutama perguruan tinggi untuk melakukan perubahan pada model proses pembelajaran dimana proses pembelajaran berpindah dari pembelajaran konvensional atau tatap muka di kelas menjadi pembelajaran online atau daring. Dengan demikian, tenaga pengajar yaitu dosen dan mahasiswa harus siap beradaptasi dan menghadapi terobosan maupun tantangan baru terhadap perubahan sistem dalam pembelajaran yang diterapkan perguruan tinggi. Learning Management System (LMS) adalah salah satu cara yang digunakan oleh perguruan tinggi untuk mendukung dan mengelola pembelajaran secara online agar proses belajar mengajar tetap berjalan dengan baik selama pandemic COVID-19. Metode penelitian yang digunakan dalam penelitian ini adalah metode semi deskriptif kuantitatif. Dimana tujuan dalam penelitian ini adalah untuk menjelaskan pemanfaatan Learning Management System sebagai media pembelajaran online yang digunakan selama pandemic COVID-19. Aplikasi Learning Management System seperti Google Classroom, Edmodo, Moodle, serta SEVIMA Edlink dan LMS yang dikembangkan oleh perguruan tinggi maupun yang disediakan oleh pemerintah sangat bermanfaat sebagai media pembelajaran online atau daring selama pandemi COVID-19. Dimana dengan aplikasi LMS ini, sistem pembelajaran dan komunikasi tetap berjalan dengan baik dengan memanfaatkan fasilitas yang tersedia dalam aplikasi LMS tersebut.
\end{abstract}

Kata kunci: komponen; Learning Mangement System, Pembelajaran Online, COVID-19

\begin{abstract}
The COVID-19 pandemic requires the education sector to make various changes and innovations and adaptations for the implementation of the learning process to continue. The COVID-19 pandemic encouraged the education sector, especially universities, to make changes to the learning process model where the learning process moves from conventional or face-to-face learning in the classroom to online or online learning. Thus, faculty, lecturers and students must be ready to adapt and face breakthroughs and new challenges to the system changes in learning implemented by universities. Learning Management System (LMS) is one of the ways used by universities to support and manage online learning so that the teaching learning process continues well during the COVID-19 pandemic. The research method used in this study is a semi-descriptive quantitative method. Where the purpose in this study is to explain the utilization of Learning Management System as an online learning medium used during the COVID-19 pandemic. Learning Management System applications such as Google Classroom, Edmodo, Moodle, and SEVIMA Edlink and LMS developed by universities as well as provided by the government are very useful as online or online learning media during the COVID-19 pandemic. Where with this LMS application, the learning and communication system continues to run properly by utilizing the facilities available in the LMS application.
\end{abstract}

Keywords: Learning Mangement System, Online Learning, COVID-19

JISICOM (Journal of Information System, Informatics and Computing)

http://journal.stmikjayakarta.ac.id/index.php/jisicom Telp.+62-21-3905050, e-mail: jisicom@stmikjayakarta.ac.id, jisicom2017@gmail.com 


\section{PENDAHULUAN}

Pandemi COVID-19 yang melanda Indonesia membuat Pemerintah akhirnya menerbitkan Peraturan Pemerintah yang mengatur tentang pembatasan sosial berskala besar. Dimana tercantum dalam PP Nomor 21 Tahun 2020 tentang Pembatasan Sosial Berskala Besar Dalam Rangka Percepatan Penanganan Corona Virus Disease $2019 \quad$ (COVID-19) pada https://nasional.kontan.co.id/news/[1]. Kebijakan physical distancing atau pembatasan sosial yang diberlakukan oleh Pemerintah kepada seluruh masyarakat Indoenesia saat Pandemi COVID-19 guna memutus mata rantai penyebaran virus COVID-19 menjadi dasar pelaksanaan proses pembelajaran dari rumah dengan memanfaatkan teknologi informasi. Berdasarkan Surat Edaran dari Mendikbud RI No 3 Tahun 2020 tentang Pencegahan COVID-19 pada satuan Pendidikan, semua perguruan tinggi di Indonesia mengambil langkah tegas dan nyata untuk mengikuti himbauan Pemerintah. Dimana sektor pendidikan diharuskan mengubah model pembelajaran secara konvensional ke pembelajaran daring atau online. Pembelajaran online atau daring sudah diberlakukan dalam beberapa tahun terakhir dalam sistem pendidikan di Indonesia seperti di perguruan tinggi. Melalui pemanfaatan teknologi informasi dalam sistem pendidikan selama pandemic COVID-19 membuat proses pembelajaran bisa tetap dilaksanakan dengan baik dimana masyarakat Indonesia sekarang ini sebagian besar sudah menggunakan fasilitas internet, seperti yang dikemukakan pada riset platform manajemen media sosial HootSuite dan agensi marketing sosial We Are Social bertajuk "Global Digital Reports 2020", hampir $64 \%$ penduduk Indonesia sudah terkoneksi atau menggunakan jaringan internet pada https://kumparan.com/kumparantech/ [2].

Pandemi COVID-19 menuntut sektor pendidikan seperti perguruan tinggi untuk melakukan berbagai perubahan maupun inovasi dan adaptasi demi pelaksanaan proses pembelajaran tetap berjalan baik. Dengan demikian, tenaga pengajar yaitu dosen dan mahasiswa harus siap beradaptasi dan menghadapi terobosan maupun tantangan baru terhadap perubahan sistem dalam pembelajaran yang diterapkan perguruan tinggi. Learning Management System (LMS) adalah salah satu cara yang digunakan oleh perguruan tinggi untuk mendukung dan mengelola pembelajaran secara online agar proses belajar mengajar tetap berjalan dengan baik selama pandemic COVID-19. Berdasarkan permasalahan tersebut, maka penulis mengambil judul tentang "Analisa Pemanfaatan Learning Management System (LMS) Sebagai Media Pembelajaran Online Selama Pandemi COVID19 '.

Learning Management System (LMS) atau Sistem Manajemen Pembelajaran merupakan suatu sistem teknologi informasi yang dikembangkan untuk mengelola dan mendukung proses pembelajaran, mendistribusikan materi perkuliahan dan memungkinkan kolaborasi antara dosen dan mahasiswa. Melalui Learning Management System (LMS) mahasiswa dapat mengakses materi perkuliahan yang diberikan, melakukan discussion board dengan dosen melalui forum diskusi, melakukan chat, serta mengakses tugas yang diberikan oleh dosen. Dosen juga didorong untuk membuat materi pembelajaran lebih kreatif melalui video pembelajaran yang bisa diupload dalam Learning Management System (LMS). LMS memberikan kontribusi dari segi pemanfaatannya. Fleksibilitas Learning Management System memungkinkan dosen maupun mahasiswa dapat mengakses LMS kapan saja dan dimana saja serta melalui berbagai device, baik melalui PC, tablet, maupun smartphone.

\section{METODE DAN MATERI}

\subsection{Metode Penelitian}

Metode penelitian yang digunakan dalam penelitian ini adalah metode semi deskriptif kuantitatif . Dimana penelitian ini merupakan penelitian yang bertujuan untuk menjelaskan fenomena yang ada dengan menggunakan angkaangka untuk mendeskripsikan karakteristik sesuatu dan menilai sifat dari kondisi- kondisi yang tampak. Tujuan dalam penelitian untuk menggambarkan karakteristik sesuatu sebagaimana adanya yaitu untuk menjelaskan pemanfaatan Learning Management System atau Sistem Manajemen Pembelajaran sebagai media pembelajaran online yang digunakan selama pandemic COVID-19. Metode pengumpulan data yang dilakukan untuk penelitian ini adalah metode observasi dan metode studi pustaka. Metode observasi dengan mengkaji data maupun informasi semi deskriptif kuantitatif yang berhubungan 
dengan penelitian pada website-website tertentu dan untuk metode studi pustaka dengan mencari sumber referensi maupun literatur atau teori yang berhubungan dengan masalah yang sedang diteliti.

\subsection{Materi}

\section{Pengertian Pembelajaran Online}

Konsep pembelajaran online adalah pembelajaran melalui Internet, di mana mahasiswa dipisahkan dari dosen di tempat atau ruang dan mungkin waktu. Pembelajaran online lebih mengedepankan kepada kemampuan siswa maupun mahasiswa dalam menerima dan mengolah informasi. Menurut Simonson, dkk dalam Yunus [3] mengemukakan bahwa: "The key to success in an online classroom is not which technologies are used, but how they are used and what information is communicated using the technologies". Artinya adalah Kunci sukses dalam suatu kelas online itu bukan pada "teknologi apa" yang digunakan, tetapi "bagaimana teknologi" itu digunakan dan informasi apa yang dikomunikasikan menggunakan teknologi tersebut. Ciri-ciri pembelajaran online menurut Flinders University dalam Riyana [4] pada www.pustaka.ut.ac.id/, yaitu personal, structured, active dan Connective.

a. Pembelajaran Individu. Pengalaman belajar pada pembelajaran online diciptakan oleh siswa maupun mahasiswa itu sendiri. Pada pembelajaran online siswa maupun mahasiswa berdiri di atas pijakan sendiri. Salah satu keuntungan dari pembelajaran online yaitu, siswa maupun mahasiswa dapat menciptakan sendiri suasana belajar yang nyaman dan sesuai keinginan. Siswa maupun mahasiswa dalam proses pembelajaran online akan belajar secara sendiri dan mandiri.

b. Terstruktur dan Sistematis. Sama dengan pembelajaran konvensional, pembelajaran secara online juga dilakukan secara terstruktur. Sebelum diadakannya kegiatan belajar mengajar secara online, terlebih dahulu tenaga pengajar menyiapkan silabus, materi pelajaran, media dan sumber belajar

c. Mengutamakan Keaktifan Siswa maupun mahasiswa. Proses belajar terjadi akibat adanya proses aktif dari siswa maupun mahasiswa. Proses aktif ini sangat diperlukan dalam pembelajaran konvensional maupun pembelajaran online. Dalam pembelajaran online, cara mengaktifkan siswa maupun mahasiswa dapat menggunakan teknologi. Teknologi dipilih, karena teknologi dapat memfasilitasi dan menyediakan berbagai macam hal yang dapat mengaktifkan siswa maupun mahasiswa.

d. Keterhubungan. Pembelajaran online tidak merubah kebiasaan-kebiasaan yang terjadi pada pembelajaran konvensional seperti adanya pertemanan, maupun interaksi dengan tenaga pengajar. Salah satu karakteristik dari pembelajaran online yaitu adanya konektivitas. Aktivitas pembelajaran online menghubungkan antara siswa maupun mahasiswa dan tenaga pengajar baik guru maupun dosen, antar siswa maupun antar mahasiswa, dan menguhungkan siswa maupun mahasiswa dengan tenaga pengajar lainnya. Melalui pembelajan online siswa maupun mahasiswa akan terkoneksi dengan dunia maya. Akan lebih banyak menemukan sumber belajar yang tidak terbatas. Dalam pembelajaran online tidak adanya batasan ruang dan waktu sehingga siswa maupun mahasiswa dapat belajar secara terkoneksi.

\section{Pengertian Learning Managemet System (LMS)}

Salah satu unsur penting dari mengimplementasikan atau menerapkan pembelajaran online yaitu dengan ketersediaan Learning Management System (LMS). Menggunakan LMS, pendistribusian materi pembelajaran serta penilaian proses pembelajaran dapat dilakukan dengan mudah. Mahnegar [5] mengemukakan bahwa, Learning Management System (LMS) merupakan suatu aplikasi atau software yang digunakan untuk me-manage atau mengelola pembelajaran secara daring atau online yang meliputi berbagai aspek antara lain materi, penempatan, pengelolaan, dan juga penilaian. Pada www.monsoonacademy.com dalam Jaqueline [3] mengnyatakan bahwa Learning Management System (LMS) adalah sebuah aplikasi software yang dapat membantu merencanakan, serta mengimplementasikan sebuah proses pembelajaran. Learning Management System (LMS) memungkinkan pemilik atau pembuat course untuk mengelola atau memanage, menyampaikan, dan memonitor para peserta didiknya. Learning Management System (LMS) memadukan antara pembelajaran tradisional dengan media digital dan 
alat interaktif meliputi pembelajaran online, virtual live sessions dan forum diskusi.

Learning Management System membantu meningkatkan pemanfaatan waktu, karena Learning Management System dapat diakses secara daring atau online dimana saja dan kapan saja. Selain itu LMS juga memiliki kualitas pembelajaran yang tidak kalah dengan cara tradisional. Ciri-ciri Learning Management System atau Sistem Manajemen Pembelajaran pada http://www.monsoonacademy.com/article/ menurut Jaqueline adalah [6] :

a. Menggunakan layanan 'self-service" atau melayani sendiri dan 'self-guided"'atau memandu sendiri.

b. Mengumpulkan dan menyampaikan konten atau materi pembelajaran dengan cepat

c. Mengkonsolidasikan inisiatif pelatihan pada platform berbasis ' 'web scalable' 'atau skala web.

d. Mendukung suatu portabilitas dan suatu standar personalisasi isi dan juga penggunaan kembali pengetahuan.

Dalam Raharja, et al [7] di dalam Learning Management System juga terdapat fitur-fitur yang dapat memenuhi semua kebutuhan pengguna dalam hal pembelajaran. penyampaian materi pembelajaran serta kemudahan akses ke sumbersumber referensi, penilaian, ujian online, pengumpulan feedback serta komunikasi yang mencakup forum diskusi online, mailing list diskusi, dan chat. Melalui Learning Management System atau Sistem Manajemen Pembelajaran, mahasiswa dapat melihat modul-modul pembelajaran yang disediakan, mengambil atau mendownload tugas-tugas dan quiz yang harus dikerjakan, melihat jadwal diskusi secara online, serta melihat nilai tugas dan quiz.

Dalam https://www.ahzaa.net/ suatu Media Info Belajar, Jenis-jenis Learning Management System (LMS) antara lain [8] :

a. Google Classroom. Google Classroom atau dikenal dengan kelas virtual atau Ruang Kelas Google, menyediakan tempat bagi mahasiswa untuk dapat berinteraksi, berkomunikasi, berdiskusi dan bekerja bersama-sama dalam sebuah kelompok dalam sistem online atau daring. Sebagai sebuah Learning Management System, Google Classroom memberikan kemudahan bagi pengguna seperti dosen dan mahasiswa dalam proses pembelajaran. Mahasiswa dengan mudah dan cepat mengumpulkan tugas-tugas mereka yang langsung terhubung melalui google drive. Dosen sebagai tenaga pengajar pun dapat dengan mudah menentukan deadline atau batas waktu pengumpulan tugas, memantau, melakukan review dan memberikan feedback atau umpan balik serta penilaian untuk tugastugas yang telah diserahkan.

1) Keunggulan Google Classroom sebagai Learnung Management System (LMS) adalah Gratis dan mudah. Google Classroom merupakan layanan gratis untuk pengguna dan memberikan fitur-fitur pengoperasian yang mudah sehingga mudah dipelajari oleh peguna.

2) Integrasi sistem. Google mengintegrasikan fitur-fitur di dalamnya seperti YouTube, Gmail Drive, dan layanan lainnya dalam satu akun.

3) Kemudahan dalam penugasan. Pengguna seperti dosen mudah memantau pekerjaan mahasiswa atau tugas yang telah mereka dibuat, siapa saja yang sudah melengkapi dan yang belum mengumpulkan tugas.

4) Fitur asignment. Fitur ini memudahkan pengguna seperti dosen dalam membuat quiz dan semacamnya yang dapat diterapkan di kelas seperti google form.

5) Form pertanyaan. Google Classroom memberikan ruang bagi pengguna seperti mahasiswa untuk bertanya tentang apa yang belum mereka pahami dalam pembelajaran.

b. Etmodo. Etmodo memungkinkan pengguna untuk membuat kelas digital dengan menggunakan fitur-fitur yang intuitif dan penyimpanan yang tidak terbatas, membuat group dengan cepat dan mudah, memberikan pekerjaan atau tugas rumah, menjadwalkan kuis serta mengelola kemajuan. Keunggulan fitur Etmodo adalah:

1) Fitur kaloborasi antara pengguna seperti dosen yang satu dengan yang lainnya.

2) Catatan pada Etmodo memungkinan mahasiswa untuk mengajukan pertanyaan singkat dan membagikan 
apa yang biasa disebut dengan status pada jejaring sosial.

3) Penyimpanan yang terorganisir untuk dokumen dengan cepat dan aman.

4) Kemampuan untuk menciptakan kelompok mahasiswa yang lebih kecil dalam kelas.

c. Moodle. Moodle adalah aplikasi berbasis web yang digunakan untuk kegiatan proses pembelajaran berbasis online atau daring. Dosen dan mahasiswa berinterasi dalam sebuah wadah ruang kelas digital berbasis $e$ learning. Dengan Moodle dapat membuat materi pemelajaran, kuiz, jurnal dan sebagainya. Keunggulan fitur Moodle adalah :

1) Assignment.. Digunakan untuk memberikan penugasan kepada para peserta pembelajaran secara online.

2) Chat. Fasilitas ini digunakan untuk melakukan proses percakapan secara daring atau online.

3) Forum. Dapat berdiskusi melalui forum yang tersedia dalam Moodle.

4) Survey dan kuis. Fitur ini memungkinkan dilakukan survey atau ujian secara online.

5) Mendukung paket pembelajaran dalam berbagai format misalnya teks, animasi video, dan juga audio.

Selain beberapa aplikasi Learning Management System tersebut diatas, ada juga salah satu Learning Management System yang merupakan karya anak bangsa yaitu SEVIMA Edlink. Pada https://sevima.com/, alam aplikasi SEVIMA Edlink terdapat beberapa program antara lain [9]:

a. Presensi online mahasiswa. Pada SEVIMA EdLink sudah dilengkapi dengan presensi mahasiswa yang bisa diakses oleh mahasiswa melalui smartphone sehingga mahasiswa akan lebih mudah mengaksesnya dimanapun dan kapanpun.

b. Video konferensi jarak jauh. Pada aplikasi SEVIMA EdLink juga sudah tersedia ruang untuk melakukan perkuliahan jarak jauh dengan menggunakan video konferensi sehingga semua sistem pembelajaran atau belajar mengajar akan sangat mudah dan leluasa dalam pelaksanaannya.

c. Jadwal perkuliahan online. Pada aplikasi SEVIMA Edlink ini, mahasiswa akan menikmati fasilitas berupa jadwal perkuliahan yang tersedia di dalam SEVIMA Edlink, dengan demikian mahasiswa akan lebih mudah dalam menjalankan perkuliahan.

d. Adanya kuis interkatif dalam aplikasi SEVIMA Edlink yang dikemas saangat menarik dan menyenangkan.

e. Sharing materi, diskusi dan kuliah online dengan mudah sehingga materi yang disampaikan dosen dapat tersaring dengan baik.

f. Rekap absen mahasiswa. Dengan aplikasi SEVIMA Edlink, dengan hanya melihat absensi yang telah dilakukan mahasiswa secara online, maka dosen bisa langsung untuk melakukan rekap dari data tersebut.

\section{Pengertian Virus COVID-19}

Dalam website Kementerian Kesehatan Republik Indonesia https://www.kemkes.go.id/ Coronavirus merupakan keluarga besar virus yang menyebabkan penyakit pada manusia dan hewan. Pada manusia biasanya menyebabkan penyakit infeksi saluran pernapasan, mulai dari flu biasa hingga penyakit yang serius seperti Middle East Respiratory Syndrome (MERS) dan Sindrom Pernafasan Akut Berat atau Severe Acute Respiratory Syndrome (SARS). Coronavirus jenis baru yang ditemukan pada manusia yang pertaama kali muncul di Wuhan Cina, pada Desember 2019, kemudian diberi nama Severe Acute Respiratory Syndrome Coronavirus 2 (SARS-COV2), dan menyebabkan penyakit Coronavirus Disease-2019 (COVID-19). [10].

Gejala umum dari virus COVID-19 adalah berupa demam 380C, batuk kering, dan sesak napas. Dalam https://www.kemkes.go.id/ dijelaskan bahwa jika ada orang yang dalam waktu 14 hari sebelum muncul gejala umum tersebut pernah melakukan perjalanan ke negara yang sedang terjangkit, atau pernah merawat maupun kontak erat dengan penderita COVID-19, dengan demikian orang tersebut akan dilakukan pemeriksaan laboratorium lebih lanjut untuk memastikan diagnosisnya. Sama halnya dengan penyakit pernapasan yang lain, COVID-19 dapat menyebabkan gejala ringan termasuk pilek, sakit tenggorokan, batuk, dan demam. Sekitar $80 \%$ kasus dapat pulih tanpa perlu perawatan khusus. Mungkin beberapa orang akan menderita sakit yang parah, seperti disertai dengan pneumonia atau kesulitan

JISICOM (Journal of Information System, Informatics and Computing)

http://journal.stmikjayakarta.ac.id/index.php/jisicom Telp.+62-21-3905050, e-mail:jisicom@stmikjayakarta.ac.id, jisicom2017@gmail.com 
bernafas, yang umumnya muncul secara bertahap. Bagi orang yang sudah lanjut usia, dan orang-orang dengan kondisi medis atau yang mempunyai riwayat penyakit yang sudah ada sebelumnya (seperti diabetes, tekanan darah tinggi dan penyakit jantung), mereka biasanya lebih rentan untuk menjadi sakit parah.[10].

\section{PEMBAHASA DAN HASIL}

Selama pandemi COVID-19 segala aktivitas atau kegiatan pembelajaran yang biasanya dilakukan di perguruan tinggi harus dilakukan secara daring atau online di rumah sehingga membuat pihak dosen maupun mahasiswa harus beradaptasi dengan perubahan baru dari proses pembelajaran yang diterapkan secara online. Perguruan tinggi dipacu untuk bisa bekerja keras, berpikir kreatif dan juga adaptif dengan cara mengubah model pembelajaran yang awalnya berbasis konvensional menjadi pembelajaran yang berbasis e-learning atau online. Learning Management System adalah salah satu media yang digunakan dalam pembelajaran online atau daring. Pemnafaatan Learning Management System atau Sistem Manajemen Pembelajaran selama pandemi COVID-19 sangat mendukung tetap terlaksananya proses pembelajaran dalam bidang pendidikan.

Pada https://edukasi.kompas.com/ oleh Irfan Kamil [11], Kementerian Pendidikan dan Kebudayaan (Kemendikbud) telah melakukan evaluasi terhadap pelaksanaan pembelajaran online atau daring yang dilakukan sejak Maret 2020, salah satunya adalah melalui survei. Dimana hal ini disampaikan oleh Pelaksana Tugas Direktur Jendral Pendidikan Tinggi Kementerian Pendidikan dan Kebudayaan (Kemendikbud) pada acara temu media Bincang Sore secara virtual pada tanggal 24 Juni 2016, bahwa pada bulan Maret, terdapat sebanyak 8 juta mahasiswa dan 300.000 dosen bertransformasi ke dalam pembelajaran online atau daring. Kemudian dari hasil survei tersebut, didapatkan hasil bahwa 70 persen menyebutkan bahwa pembelajaran daring atau online dinilai baik bahkan sangat baik, 30 persen lainnya mengakui masih adanya kelemahan seperti adanya kendala keterjangkauan dan kestabilitas jaringan yang terkadang terputus saat ada perkuliahan.

$$
\text { Dalam Salsabila [12] pada }
$$

https://tekno.kompas.com/ dikemukakan bahwa salah satu Learning Management System yaitu
Google Classroom menjadi aplikasi gratis yang paling banyak diunduh di Google Playstore dan Apple App Store, semenjak sebagian sekolah dan perguruan tinggi menerapkan kebijakan belajar dari rumah, untuk mencegah penyebaran pandemi COVID-19. Aplikasi Google Classroom telah diunduh lebih dari 50 juta kali. Pencapaian ini tergolong luar biasa, karena berdasarkan riset AppBrain, Google Classroom bahkan di luar daftar 100 aplikasi populer dan aplikasi keluaran dari Google ini sangat membantu dan bermanfaat untuk pembelajaran jarak jauh atau pembelajaran online. Dengan aplikasi ini, siswa maupun mahasiswa dapat tetap terhubung dengan tenaga pengajar meskipun saat di berada di luar. Dimana siswa maupun mahasiswa tidak bisa melihat tenaga pengajar menerangkan materi di depan kelas, namun tetap bisa belajar dengan memanfaatkan teknologi ini. Selain itu, pemanfaatan Google Classroom juga dituangkan pada https://teknologi.bisnis.com/ bahwa aplikasi Google Classroom sudah diunduh lebih dari 50 juta pengguna perangkat Android di seluruh dunia. Dimana, pada aplikasi ini tenaga pengajar dapat mengelola semua dokumen yang dibutuhkan dalam pembelajaran dan memungkinkan komunikasi antara antara tenaga pengajar dengan siswa maupun mahasiswa lebih efektif. Serta tenaga pengajar dapat membuat tugas, mengirim pengumuman, dan juga memulai diskusi kelas secara langsung Selain itu tenaga pengajar juga dapat melihat dengan cepat siapa saja yang sudah mengirimkan tugas dan siapa saja yang belum menyelesaikan tugas, serta langsung memberikan nilai dan masukan secara real-time. [13].

Selain Google Classroom. Aplikasi Learning Management System yang lain yaitu Edmodo juga dimanfaatkan untuk pembelajaran saat pandemic COVIS-19. Seperti yang dilansir pada https://www.suara.com/tekno/ oleh Novianti penggunaan Edmodo meningkat sebesar 841 persen, Selama periode pandemic COVID-19 ini, Edmodo memberikan fasislitas yang berisi video untuk pengajaran jarak jauh dan materi bagi orangtua untuk mendukung proses pembelajaran online di rumah. Siswa, mahasiswa, orang tua, dan tenaga pengajar dapat tetap terhubung dan melanjutkan proses belajar di rumah, bahkan pada saat pembelajaran pribadi tidak memungkinkan.[14]. Kemudian, aplikasi Learning Management System yang lain yang

JISICOM (Journal of Information System, Informatics and Computing)

http://journal.stmikjayakarta.ac.id/index.php/jisicom Telp.+62-21-3905050, e-mail:jisicom@stmikjayakarta.ac.id, jisicom2017@gmail.com 
dimanfaatkan untuk media pembelajaran online selama pandemic COVID-19 adalah Moodle. Pada https://nasional.kompas.com/ oleh Sodikin [15], sebelum adanya pandemi COVID19, Moodle sudah digunakan oleh beberapa perguruan tinggi, sekolah maupun perusahaan untuk pembelajran. Dimana di Indonesia tercatat ada 285 website, mulai dari website milik perusahaan, universitas, sekolah, lembaga pendidikan nonformal, hingga situs pribadi yang menmanfaatkan aplikasi Moodle Moodle menerapkan sistem pendidikan yang menghargai pemikiran siswa maupun mahasiswa. Karena siswa maupun mahasiswa boleh mengomentari materi atau modul, bahkan bisa mengirim tulisan sebagai bahan pembelajaran. Pada https://kabar24.bisnis.com/, Universitas Budi Luhur menggunakan Learning Management System berbasis Moodle, dimana setiap mahasiswa dapat memanfaatkan LMS tersebut di rumah masingmasing.[16]

Pada https://sevima.com/ ada salah satu aplikasi Learning Management System (LMS) asli dari Indonesia yang telah banyak digunakan oleh perguruan tinggi yaitu SEVIMA EdLink. SEVIMA EdLink adalah platform unggulan dari karya anak bangsa yang memiliki kualitas yang sama tingkatnya dengan produk LMS keluaran luar negeri. EdLink mampu memberikan kualitas terbaik dalam membantu para mahasiswa dan juga dosen dalam menjalankan studi atau pembelajaran secara online. Seluruh ruang dan fasilitas yang disediakan oleh SEVIMA EdLink ini sudah disesuaikan dengan mengikuti kultur pembelajaran yanga ada di Indonesia. Jadi aplikasi yang satu ini akan sangat mudah untuk dioperasikan. Saat ini SEVIMA EdLink sendiri telah dimanfaatkan oleh 270 perguruan tinggi, dan memudahkan pembealjaran daring atau online 150.000+ Mahasiswa dan 7.000 Dosen di beberapa perguruan tinggi di Indonesia antara lain Politeknik Negeri Payakumbuh, Universitas Muhammadiyah Tasikmalaya, Universitas BSI Bandung, dan masih banyak lagi perguruan tinggi lainnya.
Saat pandemic COVID-19 ini, hampir seluruh kampus melaksanakan pembelajaran daring atau online. Menurut survei yang dilakukan April lalu, 95 persen perguruan tinggi melaksanakan pembelajaran daring atau online. Direktorat Jenderal Pendidikan Tinggi juga menyediakan plaform pembelajaran daring SPADA yang dapat digunakan secara bersama-sama, terutama untuk perguruan tinggi yang belum memiliki Learning Management System (LMS) untuk pelaksanaan proses pembelajaran daring atau online. Saat ini di dalam aplikasi SPADA ada sebanyak 244 perguruan tinggi yang berbagi modul perkuliahan dan lebih dari 30.000 konten yang dapat digunakan dalam pembelajaran daring atau online. https://www.krjogja.com/pendidikan/ [17]. Selain beberapa aplikasi Learning Management System yang dimanfaatkan untuk pembelajaran online atau daring selama pandemic COVID-19 yang dipaparkan diatas, beberapa perguruan tinggi juga sudah memiliki platform Learning Managemnet System yang dikembangkan sendiri yang dimanfaatkan untuk pembelajaran selama pandemic COVID-19.

\section{KESIMPULAN}

Berdasarkan pada pemaparan pembahasan diatas dapat disimpulkan bahwa aplikasi Learning Management System seperti Google Classroom, Edmodo, Moodle, serta SEVIMA Edlink dan LMS yang dikembangkan oleh perguruan tinggi maupun yang disediakan oleh pemerintah sangat bermanfaat sebagai media pembelajaran online atau daring selama pandemi COVID-19. Dimana dengan dukungan dari aplikasi LMS atau Sistem Manajemen Pembelajaran ini, sistem pembelajaran dan komunikasi antara dosen dan mahasiswa tetap berjalan dengan baik dengan memanfaatkan fasilitas yang tersedia dalam aplikasi LMS tersebut. Dan akhirnya, peneliti mengharapkan pandemi COVID-19 dapat berakhir sehingga sistem pembelajaran bisa dilakukan secara tatap muka selain melalui online dans sistem pendidikan di Indonesia tetap maju dan menghasilkan generasi muda yang berkualitas.

JISICOM (Journal of Information System, Informatics and Computing)

http://journal.stmikjayakarta.ac.id/index.php/jisicom Telp.+62-21-3905050, e-mail:jisicom@stmikjayakarta.ac.id, jisicom2017@gmail.com 


\section{Journal of Information System, Informatics and Computing}

\section{REFERENASI}

[1] Hadinata, Haris (2020). "Hadapi Corona Pemerintah Terbitkan PP Pembatasan Sosial Berskala Besar".

https://nasional.kontan.co.id/news/hadapicorona-pemerintah-terbitkan-pp-pembatasansosial-berskala-besar

[2] Tekno \& Sains (2020). Riset : 64\% Penduduk Indonesia sudah Pakai Internet. https://kumparan.com/kumparantech/riset-64penduduk-indonesia-sudah-pakai-internet1ssUCDbKILp

[3] Yunus, Mohammad (2019) "Pembelajaran Online". Jakarta : Universitas Terbuka.

[4] Riyana, Cepi. (2019). "Konsep Pembelajaran Online”. http://www.pustaka.ut.ac.id/lib/wpcontent/uploads/pdfmk/TPEN4401-M1.pdf

[5] Mahnegar, F. (2012). "Learning Management System. International Journal of Business and Social Science", Vol.3, No.21 (2012).

[6] Jaqueline.(2019).Apa itu LMS (Learning Management System).http://www.monsoonacademy.com/articl e/151454/Apa-itu-LMS-(Learning-ManagementSystem).html

[7] Raharja, Setya, Lantip Diat Prasojo, dan Ariyawan Agung Nugroho. (2011). "Model Pembelajaran Berbasis Learning Management System dengan Pengembangan Software Moodle di Sekolah Menengah Atas”. Jurnal Pendidikan. Vol.41, No.1 (2011).

[8] Ahzaa,net. (2018). Inilah Empat Platform Learning Management System (LMS) Terbaik untuk Kelas Anda. https://www.ahzaa.net/2018/03/inilahempat-platform-learning.html

[9] Sevima. "SEVIMA Edlink, Aplikasi LMS Terbaik Karya Anak Bangsa.” https://sevima.com/sevimaedlink-aplikasi-lms-terbaik-karya-anak-bangsa/

[10]Kemenkes.(2020). "Kesiapsiagaan Menghadapi Infeksi COVID-19." https://www.kemkes.go.id/folder/view/fullcontent/structure-faq.html
[11]Kamil, Irfan. (2020). "Dirjen Dikti : 70 Persen Mahasiswa dan Dosen Nilai Pembelajaran Daring Lebih baik." https://edukasi.kompas.com/read/2020/06/28/2231 26971/dirjen-dikti-70-persen-mahasiswa-dandosen-nilai-pembelajaran-daring-lebih?page=all

[12]Salsabila, Zakia Putri (2020). “Corona Bikin Google Classroom Jadi Aplikasi Terpopuler". https://tekno.kompas.com/read/2020/03/31/102100 67/corona-bikin-google-classroom-jadi-aplikasiterpopuler

[13]Haydan, Rehza (2020). "Belajar Daring Lewat google Classroom, Simak Manfaatnya." https://teknologi.bisnis.com/read/20200609/84/125 0294/belajar-daring-lewat-google-classroomsimak-manfaatnya

[14] Novianti. Dhytia. (2020). Lewat Paket E-learning Gratis, Trafik Edmodo di Tri Meroket 841 Persen. https://www.suara.com/tekno/2020/03/27/052218/1 ewat-paket-e-learning-gratis-trafik-edmodo-di-trimeroket-841-persen

[15]Sodikin, Amir. (2020). "Moodle, Portal E-Learning." https://nasional.kompas.com/read/2008/07/31/071 9116/moodle.portal.e-learning?page $=$ all

[16]Mulyani, Devi Sri. (2020).”Sejumlah Peruruan Tinggi Siapkan Metode Belajar secara Daring". https://kabar24.bisnis.com/read/20200409/79/1225 235/sejumlah-perguruan-tinggi-siapkan-metodebelajar-secara-daring

[17]Sudjatmoko, Tomi.(2020) "PTN/PTS Indoensia Merasakan Hikmah Saat Pandemi Covid-19, Apa saja itu?". https://www.krjogja.com/pendidikan/kampus/ptnpts-indonesia-merasakan-hikmah-saat-pandemicovid-19-apa-saja-itu/3/ 